Discoveries in the biscuit tin: the role of archives and collections in the history of artists' moving image in Scotland

Sarah Neely (University of Stirling)

Accepted for publication in Moving Image Review and Art Journal published by Intellect.

Abstract:

This article examines the situation of artists' moving image works within existing archives and collections. With a specific focus on the archiving of experimental film in Scotland, the article makes use of existing research in the field, while drawing from recent interviews with artists, curators and archivists in Scotland, Ireland and Norway.

Keywords: experimental film; artists' moving image; amateur; archives; collections; Scotland; Margaret Tait

\title{
For Using
}

Material things are only tools

Or they're nothing.

Food is a sort of tool,

Fire is a warming tool,

And paint-brushes, pencils, cameras, books

All tools of a kind

For making a life

Or lives.

But too much food is poison,

Comfort a permanent anaesthetic,

And too many paint-brushes, cameras, books

Waste away as toys.

A tool has the feel of the user's hand on it

If it's a real tool.

A tool that is fully used 
Gets a bloom on it

From its own essential-ness.

All other bits and things are clutter.

(Margaret Tait 1958/2012: 87-8)

The above poem by the Scottish filmmaker and poet, Margaret Tait (1918-1999), offers a general insight into her own understanding of her work as a filmmaker. She produced over thirty short experimental films and one feature film, and accumulated a large archive of her own film footage which she would draw from in the construction of new films, a practice which imbues much of her work with a poignant sense of deep time. And yet, during her lifetime, she demonstrated little concern with the archiving of her own significant body of work. When Janet McBain of Scottish Screen Archive (what is now the National Library of Scotland's Moving Image Archive), contacted Tait about depositing her work with the archive, she wasn't interested. It was only after her death, that Tait's husband, Alex Pirie, transferred the many cans of her films from Orquil, her studio in Orkney, to the archive in Glasgow. Tait was more interested in the making of work rather than the preservation of it. She wanted to keep making films, revisiting them through exhibiting them and drawing from them in new work. Only by using them as tools in this way would they, for Tait, keep their shine.

The life, circulation and afterlife of a film is often dependent on the contexts within which it is placed. This is true in terms of production, distribution, exhibition, but also the contexts of the films' preservation and archiving process. The relatively recent shift in preference in the UK for the term 'artists' moving image' over 'experimental film' is perhaps rooted in an acknowledgement of the importance of rethinking its archival context. As Scott MacDonald writes,

Avant-garde and experimental have tended, almost by definition, to assist in the marginalization of the body of work to which these terms refer [...] Even what is probably the most successful instance of the current exhibition of at least some forms of experimental-avant-garde work - the annual Views from the Avant-Garde presentations at the New York Film Festival- remains a 
sidebar to the festival, separate from the "real films," seemingly to protect potential audiences from having to confront the full range of cinematic possibility. By continuing to use experimental and avant-garde, we maintain this implicit conceptual marginalization.

Thus, because of experimental film's associations with the marginal, the use of the term 'artists' moving image', aligning itself with veritable institutions of fine art, aims to recoup the work from the margins of film production and place it within an arguably more credible context. This increasingly used term further distances experimental moving image forms from the sometimes rigid definitions of film and cinema, enabling the inclusion of work that would not easily fit within such contexts, for instance, video art. Context helps ensure the work is understood and that it reaches intended audiences, and helps to manage expectations of those audiences. However, the difficulty with these assumptions lies in the reality that films are rarely so neatly defined. The spectrum of work by contemporary filmmakers is great and multifarious. Some of the best work does emerge from fine art contexts and is most at home in gallery exhibition spaces, other work comes from creators with film school backgrounds who may insist on their work being shown in the cinema. To further complicate matters, some of the most interesting work often comes from neither of the above, and instead from filmmakers with backgrounds in less likely subjects such as literature, anthropology, psychology, etc. Considering the multiplicity of work, and the vast range of contexts from which it can emerge, it's not surprising to witness the continuing tension over whether it is called avant-garde, experimental, artists' moving image, or even sometimes amateur - all of these categories have been, at one time or another, used strategically by filmmakers to help them articulate their own intentions for their work and its placement.

Context is important for how the work is seen and often, more crucially, whether it is seen at all. Some contexts render the work invisible. This is true, in Scott MacDonald's description cited above, where experimental work is on the fringes of festivals privileging mainstream feature-length work. It can also be true in terms of preservation and archives. For many invested in the production and exhibition of film, archives are seen as the place where films go to die. This was the case for filmmaker Margaret Tait, who repeatedly resisted the attempts of Scottish Screen 
archivist, Janet McBain to add her films to the archive's holdings. For Tait, her primary interests lay in making and showing the films rather than preserving them.

It was a view shared by Ernest Lindgren, curator of the National Film Library in 1948, who said "The word "archive" rings with a deathly sound in the world of cinema, which is so young and vital and dynamic, eager for the future and impatient of the past.' (Houston 1994: 2). It is a view still held by many today. Benjamin Cook, trained archivist and director of LUX, insists on using the term collection for describing the work they do, collection (as opposed to the term archive) implies a body of work that is active, alive to audiences and continually engaged with. Archives on the other hand, as Penelope Houston wrote, are seen as 'closed' places (115), or worse, 'a kind of long-stay prison for films, a place into whose recesses they disappeared, never to be seen again' (45).

Archives are equally diverse in terms of content and context, both of which are often greatly influenced by their institutional affiliations. Therefore, an archive resource attached to an art museum will have different collection priorities from a national film archive. As Penelope Houston argues, considering the affiliations of various archives - from museums and national film institutes to universities - the archive 'is bound to take some of its institutional tone from its surroundings.' (1994: 5). This article aims to explore the role of the archive in relation to experimental film in greater detail, taking into consideration the ways in which these kinds of affiliations impact on crucial areas of the archival process, such as the selection of material, criteria and canonization, cataloguing and access. The article will also reflect on the notion of archives versus working collections, considering the possibilities to preserve and protect moving image works while also maintaining a sense of its contemporaneous relevance.

For many filmmakers, although the particularities of exhibition contexts might be central to their own approach to their work, thinking about the longevity of their work and how it might be preserved and archived for the future is rarely a priority. Margaret Tait is one example, as I have already suggested. Wholly focused on a connection with filmmaking in the present, she spared no time for thought about the films' posterity or future existence. A few of her films were in distribution by LUX during her lifetime and enjoyed a healthy circulation at art school screenings and 
various film festivals, but for the most part her films were made available through private circulation and a one-woman distribution model which often involved Tait posting film cans (and the occasional biscuit tin) out to fellow filmmakers across the globe. It wasn't until after Tait's death in 1999 that Tait's husband Alex Pirie turned serious attention to the long-term preservation of Tait's work. Technically, a number of archives would have provided a suitable home for Tait's films. In addition to LUX, Tait's work was housed in the BFI archive - her one and only feature film, Blue Black Permanent (1992), partly financed by the BFI, is held there. Eventually, Tait's husband decided on Scottish Screen Archive. Tait's films, like the work of many artists and experimental filmmakers working across a range of formats, present challenges to the archives and collections they reside in. Her artisanal mode of production, that placed emphasis on its medium specificity, and included techniques such as hand painting or scratching directly on to celluloid, meant the restoration and preservation process was one fraught with difficult and unusual questions that were, for the most part, new to the archive. Similarly, the national context of the archive within which a filmmaker's work is placed can present certain challenges. For instance, Scottish Screen Archive may have been an obvious home for Tait's films, however, the national context within which a national archive inevitably places a filmmaker from their collection can often render experimental filmmakers invisible. Tait's films were a unique and challenging addition to Scottish Screen Archive, whose collection primarily consisted of documentary, local topical and amateur films. Tait's invisibility within a wide-range of discourses relating to Scottish cinema was certainly true within her lifetime. Her short, non-narrative films dropped off the radar in debates around national cinema, largely because of their inability to contribute to the debates around national identity that so often focused on the ways in which feature films might narrativize the nation and thus articulate contemporary cultural issues and themes. Tait is not alone in this respect. Norman McLaren, a Scottishborn artist and founder of the National Film Board of Canada's animation studio, although perhaps not to the same extent, was also largely omitted from critical studies of Scottish cinema. Even histories written specifically about artists' moving image suffer from losses incurred by the lack of attention previously given to establishing a history of early experimental works in Scotland. As the Scottish artist Louise Crawford explained, the efforts to establish a comprehensive archive of artists' 
moving image in Scotland by herself and fellow artist Ann Vance largely began in response to 'Running Time: Artists films in Scotland 1960 to now' held in 2009, an exhibition they felt overlooked many films and filmmakers. Crawford explains,

Ann was particularly irritated when she went to a screening of 'Running Time' and realized the omissions and all the artist filmmakers that were not represented. She realized at the same time how invisible those artist filmmakers are. That was what made her start thinking about archiving work from 1985-2005 and got me involved. She had already documented and listed the films that had been produced through the Film and Video Workshop. ${ }^{1}$

Nor is Scotland alone in this charge. Other examples exist where a focus on national cinemas tends to privilege the work of narrative feature filmmakers rather than the work of what are often more likely to be more internationally engaged experimental filmmakers. In her article, 'Sighting an Irish Avant-Garde', Maeve Connolly identifies a similar treatment of filmmakers in Ireland, referring to Vivienne Dick as one specific example. Dick, who spent a large amount of her career as a filmmaker working in New York, was firmly placed within a frame of reference of the International avant-garde whilst barely remaining visible within studies of Irish film (Connolly 2004). National archives also undoubtedly play a role in the canonization of national cinemas.

\section{National archives and artists' film}

Artists' moving image is housed in a number of diverse archives. National film institutes such as the Irish Film Institute or the British Film Institute, exist to support the development of national film industries, as well as ensure the archival preservation of national film collections, which often include artists' moving image work. Other large national archives such as the Cinematheque in France or EYE Film Institute in the Netherlands, provide stand-alone film archives that also serve as film museums. There are also significant regional film archive collections such as the

\footnotetext{
${ }^{1}$ Glasgow Film and Video Workshop, founded in 1983, provided support with production, screening facilities, and served as a general meeting point for those interested in filmmaking. For more detail on the film and video workshop movement in Scotland, see MacPherson (2015).
} 
Hong Kong Film Archive or even Scottish Screen Archive (although, as its new name, National Library Scotland's Moving Image Archive [NLSMIA], perhaps establishes more firmly, many would argue NLSMIA is a national archive). Universities also host a number of important film archives, such as the Pacific Film Archive at University of California, Berkeley. There are archives which have grown out of major museum collections, from the ones at MoMA and the Walker Arts Centre in North America to the National Film Centre in Japan, which grew out of the National Museum of Modern Art in Tokyo in 1952. And finally, but not exhaustively, there are also stand-alone film collections dedicated to experimental film and/or artists' moving image work, such as Lightcone in France, FilmForm in Sweden, Arsenal in Berlin, or even more specialised initiatives such as the Norwegian Video Art Archive or the REWIND Collection in Scotland, which hosts a major archive in British Video Art. ${ }^{2}$ Both of the latter ventures go some way to ensuring the preservation of work that has in many instances been historically marginalised (Paasche, interview, 2015). Major collections and archives have also grown out of artists' and filmmakers' co-ops, namely, the Anthology Film Archives in the United States, and LUX (which was formed from a merger between London Filmmakers' Co-op and London Video Arts in 1999) in the United Kingdom.

The institutional context for each type of archive or collection inflects the way in which artists' moving image work is selected, handled, presented and generally interpreted. The various institutional contexts all present their own unique opportunities as well as challenges. To take up the example of Scotland once again, despite the prevalence of artists' moving image work in recent years, there is still no dedicated collection or archive. Many major Scottish artists working with moving image, such as Luke Fowler, have their work housed outside of Scotland (e.g. in addition to being represented by the Glasgow-based gallery, the Modern Institute, Fowler's films are held within LUX's collection). However, the work of the majority of artists remains difficult to locate. As Louise Crawford explains,

artists who are working in film and video and are now well established and have galleries probably have their work in collections or have their work

\footnotetext{
2 Although REWIND does have affiliations with other institutions. For instance, master copies of works have been deposited with the University of Dundee and National Library Scotland's Moving Image Archive.
} 
documented by their gallery. I'm thinking of Luke Fowler, Roddy Buchannan, Torsten Lauschmann. But it would seem that there are a lot of artists/filmmakers whose work is held at home and at best available on a website if they have one and it's doubtful whether their older work has been digitized and is visible or not. (Crawford, interview, 2015).

Without the existence of a dedicated archive or collection, after a moving image work's initial round of screenings, the work is therefore likely to be become lost and wholly invisible. This means that a contemporary understanding of artists' moving image culture in Scotland can only ever be a rather dampened down, shallow representation of what is in reality a very rich history. Although there is minimal representation of experimental film or artists' moving image works in NLSMIA, as mentioned previously, because the archive's focus has never been on experimental work or artists' moving image, the collection of work by relevant artists or filmmakers has never been a priority. With limited resources, priority is generally given to other kinds of factual film. This continual marginalisation of what is in Scotland a moving image culture which rivals its feature film production, speaks more widely to the lack of value that still haunts experimental film. Similarly, the presentation of the archives' collection has also reflected the prioritisation of their collection, meaning that artists' moving image work is not always visible to the archive's users. So, for instance, although copies of moving-image work that was funded by the Scottish Arts Council over the years was, by requirement of the funding guidelines, deposited with the archive, little of the work has been catalogued.

Echoing similar concerns over the fragmentation of skills and expertise in relation to moving image archives and collections, Louise Crawford concludes that 'for the future of preserving artists' film and video there has to be a collaboration or a partnership between a smaller arts/distribution/archive organisation who will deal with the specificity of artists/experimental film and a larger institution which can guarantee stability and the right conditions for conservation.' (Crawford, interview, 2015). While many specialist collections provide the appropriate contexts for artists' moving image work, they are not able to serve as a comprehensive archive. As Mason Leaver-Yap, former director of LUX Scotland, explains, LUX Scotland 
doesn't 'have the capacity to be both' a collection and archive. Like Crawford, Leaver-Yap identifies the potential for partnerships. For instance, Leaver-Yap suggests a scenario could exist whereby for every moving image work added to LUX Scotland's collection (as a distribution copy) there could also be an archival copy that is deposited with an organisation such as NLSMIA or the National Galleries of Scotland, or another institution that is able to provide long term safe storage for the work (Leaver-Yap, interview, 2015). In many ways, the role of LUX Scotland is likely to provide an important joining up of the constellation of resources, as well as a deepening sense of the context that is needed in order to establish a meaningful understanding of artists' moving image in Scotland. Ben Harman, director of Stills gallery in Edinburgh and former curator of Contemporary Art, Gallery of Modern Art in Glasgow, sees the formation of LUX Scotland as filling the gap in support for moving image work in Scotland, and that ' there should have been something like that around for a long time' (Harman, interview, 2015).

Looking elsewhere, to other archives in Europe, a similar pattern emerges. Marit Paasche, head of research at the Norwegian Video Art Archive, describes how historically, 'there has been a kind of black hole existing between the film and the visual art scene, mostly because they have had a separate distributions and economies.' (Paasche, interview 2015). Similar to Scotland, the different frameworks for the production and distribution of artists' moving image work often means it isn't considered within the wider contexts of Norwegian moving image culture and Norwegian cinema. In relation to artists' moving image works in Ireland, Maeve Connolly explains how although some recent initiatives such as the website, Irish Film and TV Research Online ${ }^{3}$, do give some small attention to experimental work (of the 39,422 records a keyword search for experimental brings up 21), significant moving image artists such as Gerard Byrne, Jaki Irvine, Siobhan Hapaska and Grace Weir do not feature at all. Connolly explains the oversight as likely to be down to the fact that the project was funded by the Irish Film Board and the work of the omitted artists were largely funded by the Arts Council (Connolly 2007). Again, like the black

${ }^{3}$ Irish Film and TV Research Online, <https://www.tcd.ie/irishfilm/> , accessed 10 December 2016. 
hole described by Paasche above, an artificial gulf is created between moving image cultures when the work is simply defined by the way it was funded. There are also obvious difficulties dealing with cataloguing, but also handling, the wide variety of formats that are represented by works funded by the Arts Council. The process of integrating the work into the Irish Film Archive's catalogue and lending system is an ongoing project that is currently being undertaken. When I went to the archive in summer 2015, there was no way of identifying certain material in the archive without having previous knowledge of its existence from Connolly's research (ibid.). As is the case with many archives, the best way of learning about an archive's holdings and how to access it, is by having a conversation with the archivist (or, in this case, a researcher who knew the collection well).

The scenario represents a familiar tension between the positioning of the work of artists' moving image work within large international or national film archives. As Kirsten Alfarao writes in reference to Caroline Frick's work in her book Saving Cinema, 'film preservation is fueled by the notion of heritage conservation, where cultural artefacts propel a nation's history into the future' (2012:47). In many film archives, it is the work which is deemed to be an artefact best able to contribute to the telling of this history that is prioritised. It is a reality that makes challenging work for the researcher of experimental film or artists' moving image and, at its worst, can mean certain kinds of moving image work becomes overlooked in critical research and writing. As Groschke, Koerber and Meiller write in relation to the neglect of experimental film in larger film archives in Germany,

experimental film as a topic is not typically existent in the large paper archives of film corporations and the trade papers now available in institutions like ours, or in libraries and university collections, which are vital sources for film scholars and their writing and rewriting of film history. The world of experimental film-making remains small and depends on personal relationships between artists, archivists, and scholars, and no machine of professionally produced public relation material that has now turned into an archival resource supports and promotes it.

(Groschke, Koerber, Meiller 2012:129). 
It is in this context that they identify the importance of the Deutsche Kinemathek Archive for providing a home for German experimental film (mainly from the 1960s and 70s). The establishment of specialist archives, such as Deutsche Kinemathek or Anthology in the United States, has served to address the invisibility of experimental film in existing contexts. As Alfarao explains in relation to Anthology, although it opened in 1970, its 'fermentation begins in the 1960s, when experimental film access was scarce and geographically specific, thriving most prominently in New York and San Francisco, where its viewers relied heavily on word-of-mouth domestic viewings, membership screenings, and alternative public spaces.' (2012: 46). Similarly, the archive and exhibition project founded by filmmakers Gregory Markopolous and Robert Beavers, which Mark Webber describes as a 'monographic archive for the preservation, presentation and study of their work', grew out of their desire to create and show work in contexts that were free from institutional constraints (2014: 11). The project's title, 'Temenos', taking its name from the ancient Greek word 'sacred grove' or 'piece of land set apart', reflects both the actual space of where Markopoulos and Beavers screened their work (e.g. a field in rural Greece), but also the necessity for experimental work to have its own dedicated spaces (12). Certainly, although a 'monographic archive' which side-steps many of the problems around visibility associated with larger collections and archives may seem ideal, it is an exception rather than the rule, and one that is faced with many challenges, especially in terms of ensuring the archive's continuation and legacy. For instance, as Webber points out, Temenos has always been reliant on the generosity of its patrons. In recent years, Temenos has been partly funded by the popular crowd-funding platform, Kickstarter. The archive's survival is also down to the devotion of an individual acting as an informal untrained archivist (i.e. Robert Beavers). Outside of these exceptional examples of the 'monographic archive', in larger archives where work must exist alongside a great number of works by other filmmakers from a diverse range of genres and forms, the processes of selection for the archives and their acquisition policies, as well as the way in which the holdings are classified and catalogued, become of crucial importance. Furthermore, in smaller nations such as Scotland or Ireland, the unlikeliness that a more specialist archive dedicated to the preservation of artists' moving image is able to be sustained over the long-term, means that the situation of artists' moving image within larger moving image archives must be taken seriously. 


\section{What's there and what's visible: processes of selection, acquisition, classification and cataloguing}

What is in the archive can be the result of a number of factors. With all archives there is an element of chance in relation to the material which it is presented with, but the process of taking in and soliciting new acquisitions, regardless of institutional attempts to objectivise the process, inevitably involves processes of selection and taste. To use Bordieu's notions of cultural capital, these decisions are likely to draw from existing social and cultural hierarchies which will serve to establish their own hierarchical patterns within the holdings of the archive itself.

The process of selection and subsequent hierarchies established within the archive also exerts its own kind of influence on those who refer to the archive. As Penelope Houston writes in her seminal text on the film archives, 'Archives influence taste by what they choose or are able to make available; even more by what they put their weight behind' (1994: 131). Furthermore, in addition to what is in the archive, the classification and cataloguing of work, and the general situation of the work within the archive's collection plays a great role in determining what is most visible, or even visible at all, within the archive. As Houston argues, 'effective access may depend on effective cataloguing, one of the most time-consuming and least visibly productive parts of the whole archive process' (97). Archive holdings first and foremost need to at least appear in some form within the catalogue in order for potential users to gain access. Once this happens, there is still the question over how the work is catalogued. Experimental film and/or artists' moving image is often categorised under the generic category of short film. In some cases, the experimental nature of the work, and its divergence from mainstream conventions, can mean that it is interpreted as 'amateur'. In many instances, the task of locating an avant-garde or experimental tradition involves mining for films relegated to a wide variety of categories - from short film, to documentary, to amateur.

Recent work on American avant-garde film has reconsidered the role of amateur filmmaking activity and film clubs in the formation of an early avant-garde. Bruce 
Posner's, Unseen Cinema project, which culminated in the 2005 release of a DVD including 155 films and running over nineteen hours, counters the argument that 'there was no early American avant-garde cinema'. Taking Lewis Jacob's 1947 essay on experimental film in America as his starting point, Posner sets out to fill in the gaps he perceives in Jacob's outline of an early avant-garde. A key objective of the project was to reassess holdings of various archives with a view to bracket a variety of films such as amateur films within the context of American avant-garde. The project succeeded on many levels, including its ability to generate debates around the difficult yet important task of classification. Richard Koszarski's review of the Unseen Cinema project in the journal Film History, while congratulating the projects' coordinators for their exposure of lesser-known films and filmmakers, also draws a question mark over some of the curatorial decisions and terminology used for the films, questioning whether terms like experimental and avant-garde are simply interchangeable, or if there is a more complex and defined relationship between the two (2008: 16). A detailed contextual understanding of individual works is essential for enabling more nuanced interpretations of the various generic categories. Furthermore, definitions of experimental film can often be easily applicable to various types of 'amateur' filmmaking. The defining characteristic of amateur as 'work created for private, not commercial use' ${ }^{4}$, also may seem in line with the necessity for some experimental filmmakers to continue to make work without financial profit. However, most experimental filmmakers did seek wider visibility for their work and engaged in networks to achieve this, even though the networks themselves may not have had commercial viability.

Certainly, in relation to Scotland, the task of locating a history of Scottish AvantGarde involves a hefty engagement with its rich history of amateur film. Partly, this is because much experimental work has historically been catalogued as amateur. For instance, some of Margaret Tait's films initially appeared in the Scottish Screen Archive catalogue under the label of amateur. But it is also because the strong tradition of amateur film in Scotland served an important function in the development of an approach to filmmaking that opposed existing forms of filmmaking which had

\footnotetext{
4 'The Moving Image Genre - Form Guide', Moving Image Research Center, Library

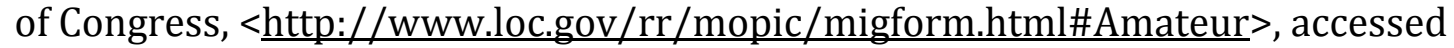
10 December 2016.
} 
been established in Scotland in the first half of the twentieth century. Similar to Ireland, early representations of Scotland were largely limited to Hollywood and British feature films. For the most part, early indigenous filmmaking consisted of documentary. It was within these narrow confines of indigenous film production that amateur film production presented (and continues to present) a unique opportunity for broadening the scope of representation. In this respect, a study of amateur film in both Ireland and Scotland can also offer an interesting contrast to the more 'official' representations of the documentaries of the period (Connolly 2007). Amateur filmmaking also provided filmmakers with an outlet and support network for producing films at a time when indigenous production was scarce. It is no surprise that it was the Scottish Amateur Film Festival that first showcased the work of one of Scotland's most significant experimental filmmakers, Norman McLaren. ${ }^{5}$

The project of ensuring the visibility of experimental moving image histories is both an academic and archival one, one that involves ensuring the visibility of work in existing collections, making links between various disparate collections, and drawing together the subtle formations of what is essentially a minor cinema. In Scotland and in many other contexts, the reality is that the project of safe-guarding the longevity of avant-garde work has not been taken up by academics or archivists, but instead, has largely been led by the interests and commitment of artists and filmmakers themselves who, through their own research, often in relation to the curation of film programmes, have assembled their own archives and histories. In recent years in Scotland, the need for contemporary artists and filmmakers to connect with a historical tradition and body of work in Scotland has proved a tangible one. For instance, LUX Scotland has placed the project of mapping such a history at the forefront of their agenda. ${ }^{6}$ Yet, although LUX Scotland currently plays a vital role in

\footnotetext{
5 In 1935, McLaren's film, Colour Cocktail, attracted the attention of John Grierson, who was the festival's adjudicator that year (Neely and Riach 2009: 2). ${ }^{6}$ In 2014, the year in which they were established, LUX Scotland piloted a touring programme entitled Where I Am, taken from the name of one of Margaret Tait's films. The programme was conceived of as a 'generative touring programme' including a list of films and filmmakers that could be added to by members of the community as it toured throughout Scotland. This generative component in particular helps to meet the project's primary aim in ensuring the programme 'showcases the rich tradition of artists' filmmaking in Scotland, and begins a conversation with audiences, venues and
} 
developing a sense of historical lineage to contemporary artists' filmmaking in Scotland, and they are in the process of developing their own collection of work by Scottish artists, their function as a collection is quite different from that of an archive. Although they are interested in the history of relevant moving image work in Scotland, their task is not to create a corresponding archive of that work. Instead, the films exist in a variety of archives and collections, from LUX's main collection, to National Library of Scotland's Moving Image Archive, and even the National Film Board, Canada, who hold the main collection of Norman McLaren's work. The contrasting remits and priorities of the various organisations - their points of connection, but also disconnection - can mean that there is a risk that films will continue to get lost between the gaps. To minimise this risk, there needs to be more open communication between organisations and a sustained commitment to looking at the bigger picture.

Collaboration is often key, a fact recognised by the Yorkshire Film Archive in a 2005 report commissioned to address the lack of attention given to artists' film and video, which points to Scottish Screen archive's collaboration with LUX on the restoration of Margaret Tait's films as an example of good practice. Similarly, the Irish Film Archive restored Vivienne Dick's early work from the 70s and 80s in collaboration with the Museum of Modern Art. It is important to note this element of collaboration involved in many of the archives' success stories in relation to artists' moving image work. The diversity of expertise required in relation to the different types of work held in archives (e.g. in relation to the demands required of particular formats), often commands input from a variety of individuals and institutions. The need for this kind of diversity of expertise is recognised in the policy of some national archives, such as the Swedish Film Institute, where the formation of specialist committees to consider holdings and acquisitions that specifically relate to experimental film.

\section{Formats and artists' moving image}

In her consideration of the archiving of artists' film and video in Ireland, Connolly points out that even if the Arts Council, who award funding for the majority of artists' films in Ireland, required award winners to deposit copies of work with the archive,

artists about what might constitute a distinctly Scottish tradition in both a national and international context.' (http://luxscotland.org.uk/events/where-i-am/). 
there are too many issues with their preservation and access due to the wide range of media formats and the particular forms of presentation - from multi-screen projection to site specific work - that each individual work demands (2007). The rise of digital filmmaking has also brought with it a great variety of formats. As Haden Guest, director of the Harvard Film Archive, explains,

The dominant use of digital video by today's avant-garde filmmakers has given rise to a seemingly endless quantity of proprietary moving image formats that have created a chaotic situation for the exhibition of digitally born experimental cinema. The absence of an accepted exhibition standard for digital work is as vexing for archives as is the absence of a rigorously tested standard for the long-term archival storage of digitally born moving images (Guest 2012: 93).

One of the additional challenges in relation to the preservation and exhibition of experimental film in recent years has been around the diminishing support for analogue film. Facilities for creating new analogue film prints are hard to come by and increasingly expensive. Venues for the projection of analogue film and the availability of projectionists and archivists with appropriate levels of skills for dealing with analogue film is also disappearing. Writing in 2013, Jon Wengtröm, curator of archival collections at the Swedish Film Institute, describes a situation whereby

If one wishes to enjoy un-digitized films in their original splendor, one would have to come to the archival cinemas, where $35 \mathrm{~mm}$ projection equipment will be maintained. The possibility of viewing all the films in the collections is thus preserved, and cinema screenings will become the equivalent of museum practice. If you want to enjoy a screening of a Swedish film classic until it has been digitized you have to travel to Filmhuset in Stockholm, just as you have to travel to the National Museum if you want to enjoy an original painting.

Many other critics (e.g. Birchall 2012, Guest 2012) have compared the special qualities of studying a film print with the practice of studying original paintings. Guest writes, 'In time, experimental film screenings would grow even closer to museum exhibitions, with film prints treated and understood as unique art objects, similar to paintings or sculpture' (2012: 91). Obviously, in order for film to be 
relegated this status, it requires a rather particular and significant set of demands in terms of the works' preservation. As a consequence, it is increasingly less likely to see films exhibited in their intended format, even in the archives where they are held. ${ }^{7}$

Some see a reluctance to digitise work as a kind of professional suicide; 'artists who are unwilling to see their work digitized or presented through aggregators like UbuWeb may find themselves written out of future canons' (Birchall 2012:14). Others maintain that there is room for a variety of projection formats to exist in tandem. As Scott MacDonald convincingly argues 'the advent of digital projection should not have meant $[\ldots]$ the demise of $16 \mathrm{~mm}$ exhibition, any more than the invention of the electric guitar should have meant the demise of acoustic guitars' (2012:87). However, for artists and filmmakers who have worked, or still work, with analogue film, difficult decisions are to be made. Artist and archivist Bill Brand writes,

As a preservationist and as an artist, I am still uncertain whether the works I preserve should be transformed to accommodate emerging distribution channels and audience formations or if it is more important to limit these works to their traditional exhibition formats, to preserve the viewing experience of the period in which they were made. (2012:94).

For artists and filmmakers who are no longer living, matters are further complicated as decisions are made on their behalf by others. In contrast to the decision to maintain works in their originally intended analogue formats, the decision to transfer works into digital formats ultimately results in the generation of new works. The decision transfer of work to new technologies is one likely to be fraught with challenges. Marit Paasche acknowledges the significance of this role in relation to the work of the Norwegian Video Art Archive, 'We do violate the original form when we transform a video installation to a digital work, or we create a new work, depending on how you look at it.' (Paasche, interview 2015).

Nevertheless, the rise in digital technologies and online platforms supporting the exhibition of artists' moving image has inevitably brought the work to new audiences.

\footnotetext{
${ }^{7}$ For instance, NLSMIA's newly opened premises in Kelvin Hall, Glasgow, featuring state-of-the-art exhibition spaces, including a 12-screen interactive video-wall, does not have the facility to offer analogue projection.
} 
In line with the general narratives describing the democratising potential of the Internet (see Castells 2007, 2011), online platforms such as Ubuweb and Vimeo have supported the creation of online collections, enabling artists and filmmakers to circulate their work more widely. Digital technologies have also facilitated the creation of databases which draw together a number of disparate archive sources and collections. For instance, the online Film \& Video Distribution Database (FVDD), an archive of paper documents which developed from an Arts and Humanities Research Council (AHRC)-funded project led by Julia Knight and Peter Thomas from 20022005, enables users to search across a number of different archives and collections, such as LUX and Cinenova.

The increasing number of archives making at least some of their collection available for online viewing, from National Library of Scotland's Moving Image Archive to LUX, and the National Film Board Canada, has also brought new audiences to work that had previously only been seen by the few able to attend relatively rare screenings. In relation to the Swedish Film Institute, Jon Wengtröm writes,

The shift to digital technology has not only provided archives with the chance to make the heritage more available, but has forced archives to go back and reinvestigate their collections, and to valorize and curate the collections in a different way. You could argue that shorts, non-fictions films, commercials and other types of commissioned films have been «waiting» for new technologies or new platforms to emerge and develop. (2013: 129)

While there is an obvious democratising potential in the digitisation of work, the costs involved are not negligible. The expenses of digitisation mean that for many archives processes of selection determine what material is digitised and what isn't. Marit Paasche describes how even though the initial cataloguing at the Norwegian Video Art Archive, and mapping of Norwegian video art, was able to be wholly inclusive, the financial constraints of digitisation required a more strategic process of selection. She explains,

Given the limited amount of minutes allowed for the digital archive, we have found it crucial that the contents of the archive should be as varied and plentiful as possible when it is handed over to the Arts Council at the 
completion of the project (Summer 2015). The richer the resource archive, the better the starting point for telling a wide range of stories about a specific time period, context or trend. (Paasche, interview, 2015)

Furthermore, the digitisation of work is not a one-off process. The developing technologies in the quality of digital transfers means that work that was digitised ten years ago is likely to now seem poor quality. Even in cases where large collections are able to be digitised and made publicly available, the challenge then becomes how to ensure the work doesn't again become lost in the digital tangle of vast online collections. As Danny Birchall argues, this is a challenge increasingly facing the online spectator,

For the audience, the problem now is less how to see it than where to begin, and how to organize, or even understand, it. For archives, co-ops, and filmmakers themselves, the question is whether a vast new audience for the work comes at an unacceptable cost to the integrity of the works themselves.

(Birchall 2012:12).

It's not enough for archives to simply make everything available within online platforms. The context for the work is still a crucial component in the process of exhibition, both online and offline. As Paasche explains of her work in the Norwegian Video Art Archive, 'understanding what makes a work meaningful is as important as working out the technical formats' (Paasche, interview 2015). Context was also important for the project. As Paasche describes,

Understanding the larger context surrounding early video work was mainly what made us do the in-depth interviews with six different artists in Lives and Videotapes: The Inconsistent History of Norwegian Video Art. This book attempts to reveal how, why, and under what circumstances many of the early video works made in Norway came about — and what makes them important for posterity. (Paasche, interview 2015)

As Paasche is acutely aware, 'the practice of archiving holds great power of definition' (Paasche, interview 2015). The decisions made about what is preserved and how it is presented, and in what contexts it is situated, arguably plays the most significant role 
in the way the histories of moving image are written and understood.

\section{Collections versus archives}

There is much potential in the proliferation of archives emerging in new online platforms, but there is still a risk of even these serving as a kind of long-stay prison if context is forgotten about. Collections such as LUX or the British Artists' Film and Video Study Collection (BAFVSC) serve to keep the work of artists' and filmmakers alive through, as Margaret Parsons writes in relation to the BAFVSC, 'contextualizing the culture that surrounds the practice and presentation of experimental film, shedding light on its larger social, historic, aesthetic, and economic connotations. (Parsons 2012: 90). Similarly, as Kirsten Alfarao writes in relation to Anthology in the US, context is prioritised 'By incorporating digital access to paper materials, journals, audio, and photographic stills, Anthology is creating an online film study center parallel to the one originally established in 1970' (2012: 48). In Scotland, a collaboration between organisations such as LUX Scotland and National Library of Scotland's Moving Image Archive, could also offer the kind of context necessary to fully illuminate the rich history of artists' moving image in Scotland. The work is there, we must not take it for granted. The work must be looked at, written about, talked about and fully engaged with in the way that is described in Tait's poem at the start of this article. As she writes, 'A tool that is fully used gets a bloom on it'.

\section{Bibliography}

Alfarao, Kirsten (2012), 'Access and the Experimental Film: New Technologies and Anthology Film Archives' Institutionalization of the Avant-Garde', The Moving Image, 21: 1, pp. 44-64.

Birchall, Danny (2009), 'The Avant-Garde Archive Online', Film Quarterly, 63: 1, pp. 12-14.

Blaetz, Robin (2006), 'Rescuing the Fragmentary Evidence of Women's Experimental Film', Camera Obscura, 21: 63, pp. 152-156.

Bourdieu, Pierre (1984), Distinction: A Social Critique of the Judgement of Taste, trans. ed., London: Routledge. 
Bourdieu, Pierre (1993), The Field of Cultural Production: Essays on Art and Literature, edited by R. Johnson, Cambridge: Polity Press.

Brand, Bill (2012), 'Artist as Archivist in the Digital Transition' in D. Orgeron and M. Ogeron (eds.) 'Experimental/Avant-Garde Moving Images and the Archive: A Virtual Roundtable', The Moving Image, 12: 1, pp. 92-5.

Castells, Manuel (2011), Communication Power, Oxford: Oxford University Press.

Castells, Manuel (2007), 'Communication, Power and Counter-Power in the Network Society', International Journal of Communication 1, pp. 238-266.

Catapano, Peter (1994), 'Creating "Reel” Value: The Establishment of MoMA's Film Library, 1935-37', Film and History, 24:3, pp. 29-46.

Clifford, James (1998), 'On Collecting Art and Culture' in The Predicament of Culture: Twentieth-Century Ethnography, Literature, and Art, Cambridge, MA: Harvard University Press, pp.215-251.

Connolly, Maeve (2014), Entry on 'time-based' art in Ireland (from late 1960s to early 2000s), in P. Murphy (ed.), Art and Architecture of Ireland, Volume Three: Sculptors and Sculpture 1600-2000, Dublin and New Haven: Royal Irish Academy and Yale University Press, pp. 530-533.

Connolly, Maeve (2007), 'Interrogating the Archive: Artists' Cinema in Ireland' (unpublished conference paper), Future Histories of the Moving Image, University of Sunderland, 16-18 November.

Connolly, Maeve (2004), 'Sighting an Irish Avant-garde in the intersection of Local and International Film Cultures', boundary 2: International Journal of Literature and Culture, 31: 1, pp. 244-265.

Crawford, Louise (2015), interviewed by Sarah Neely (email), 11 May.

Eyles, Allen and Meeker, David (eds.) (1992), The Missing Believed Lost: The Great British Film Search, London: BFI.

Gartenberg, Jon (2007), 'The Fragile Emulsion',, Journal of Film Preservation, 73, pp. 39-51. 
Groschke, Annette, Koerber, Martin and Meiller, Daniel (2012), 'Who is Going to Look at That? Experiences, Possibilities and Pitfalls of Keeping Experimental Film in a Mid-sized Film Archive', The Moving Image, 12: 1, pp. 128-135.

Guest, Haden (2012), 'Notes from a Cautious Optimist' in D. Orgeron and M. Ogeron (eds.) 'Experimental/Avant-Garde Moving Images and the Archive: A Virtual Roundtable', The Moving Image, 12: 1, pp. 91-2.

Harman, Ben. (2015), interviewed by Sarah Neely, Glasgow, 7 May.

Harrison, Harriet W. (ed.) (1991), The FIAF cataloguing rules for film archives, Saur. Houston, P (1994), Keepers of the Frame: The Film Archive, London: BFI.

Jeffrey, Moira (ed.) (2014), Generation: 25 Years of Contemporary Art in Scotland (reader), Edinburgh and Glasgow: National Galleries of Scotland and Glasgow Life.

Koszarski, Richard (2008), 'Book Review: Unseen Cinema', Film History, 20:1, pp. $115-8$.

Mason Leaver-Yap (2015), interviewed by Sarah Neely, Glasgow, 29 April.

Lindgren, Ernst (1948), ‘The Importance of Film Archives’,London: Penguin Film Review, No. 5.

MacDonald, Scott (2012), ' Marginalization: Historical/Terminological' in D.

Orgeron and M. Ogeron (eds.) 'Experimental/Avant-Garde Moving Images and the Archive: A Virtual Roundtable', The Moving Image, 12: 1, pp. 87-88.

MacPherson, Robin (2015), 'Cultural Crossover: Radical and Engaged Cinema' in B. Nowlan and Z. Finch (eds.) Directory of World Cinema: Scotland, Bristol and Chicago: Intellect, pp 31-45.

Neely, Sarah (2016), Between Categories: The Films of Margaret Tait: Poetry, Portraits, Sound and Place (Oxford: Peter Lang).

Neely, Sarah and Riach, Alan (2009), 'Demons in the Machine: Experimental Film, Poetry and Modernism in Twentieth-Century Scotland' in J. Murray, F. Farley and R. Stoneman (eds.) Scottish Cinema Now, Newcastle upon Tyne: Cambridge Scholars Press, pp. 1-19. 
Paasche, Marit. (2015), interview with Sarah Neely (email), 22 April.

Parsons, Margaret (2012), "'Still Separate....but Equal"?' in D. Orgeron and M. Ogeron (eds.), 'Experimental/Avant-Garde Moving Images and the Archive: A Virtual Roundtable', The Moving Image, 12: 1, pp. 89-91.

Pierson, Michele (2005), 'Amateurism and Experiment: The British Film Institute's Experimental Film Fund (1952-1966)', The Moving Image, 5:1, pp. 68-94.

Rodowick, D. N. (2007), The Virtual Life of Film, Cambridge: Harvard University Press.

Russell, Catherine (1999), Experimental ethnography: the work of film in the age of video, Durham, NC: Duke University Press.

Tait, Margaret (2012), Margaret Tait: Poetry, Writings, Stories, Sarah Neely (ed.), Manchester: Carcanet.

Webber, Mark (ed.) (2014), Film as Film: The Collected Writings of Gregory J. Markopoulos, London: The Visible Press.

Wengström, Jon (2013), 'Access to film heritage in the digital era - Challenges and opportunities', Nordisk Kulturpolitisk Tidskrift, 16: 1, pp. 125-136.

Williams, Alan (2001), Film and Nationalism, New Brunswick, N.J.: Rutgers University Press.

Zryd, Michael (2008), 'Experimental Film and the Development of Film Study in America', in L. Grieveson and H. Wasson (eds.), Inventing Film Studies, Durham, N.C.: Duke University Press, pp. 182-212. 